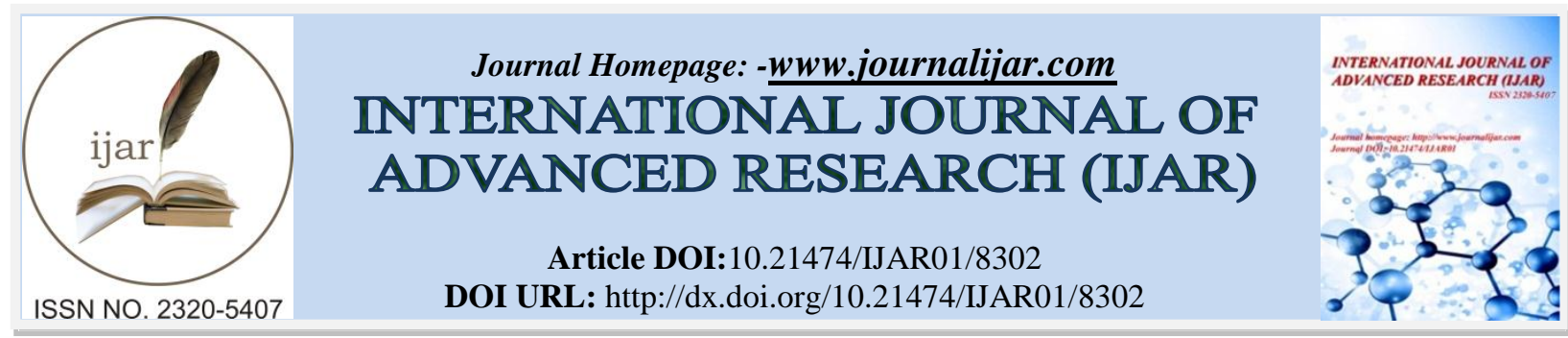

RESEARCH ARTICLE

\title{
ANTIMICROBIAL AND GCMS ANALYSIS OF CHLOROFORM EXTRACT OF PSEUDARTHRIA VISCIDA (L.) WIGHT AND ARN. AND ASSOCIATED MAJOR FUNGAL ENDOPHYTE.
}

Delmy Abraham, Bharath Nair and G. E. Mallikarjunaswamy.

Department of Forest Pathology, Kerala Forest Research Institute, Peechi-680653, Thrissur, Kerala.

\section{Manuscript Info}

\section{Manuscript History}

Received: 01 November 2018

Final Accepted: 03 December 2018

Published: January 2019

\section{Key words:-}

Pseudarthria viscida, Endophyte, Chloroform extract, Antimicrobial, GCMS.

\section{Abstract}

Pseudarthria viscida a member of Fabaceae family possess great medicinal attributes.The present study dealt with antimicrobial ability of chloroform extract P. viscida and its associated major fungal endophyte and their phytochemical analysis via GCMS. Pseudarthria viscida yielded two endophytes Colletotrichum gloeosporioides ( $\mathrm{Pv}-1)$ and $\mathrm{C}$. lindemuthianum $\left(\mathrm{Pv}_{-}\right)$and isolation frequency resulted $\mathrm{C}$. gloeosporioides $(\mathrm{Pv}-1)$ to be major one. Chloroform extracts at different concentrations $(25,50,75$ and $100 \mu l)$ of P. viscida leaves, mycelial mat $(\mu \mathrm{g} / \mathrm{ml})$ and culture filtrate $(\mathrm{v} / \mathrm{v})$ of major endophyte C. gloeosporioides $(\mathrm{Pv}-1)$ were tested for their antimicrobial activity against two bacterial species, Escherichia coli and Staphylococcus aureus and two fungal species, Fusarium oxysporum and Cladosporium cladosporioides respectively. The extracts were found to show inhibitory activity against all the studied pathogens. GC-MS analysis of both plant and fungal endophyte resulted in the presence of 16 compounds from P. viscida plant extracts, 16 from 16 from Pv-1 C.F. and 20 from Pv-1 M.E. In case of P. viscida and its endophyte Pv-1, 2, 4-Ditert-butylphenol, E-14-Hexadecenal, E-15-Heptadecenal, 1Hexadecene, Cyclotetracosane, Octadecyl trifluoroacetate were similarbut their area percentage varied. Majority of the compounds from extracts were identified to possess therapeutic properties and further chemical evaluation is needed for its successful application.

Copy Right, IJAR, 2017,. All rights reserved.

\section{Introduction:-}

Medicinal plants and products derived from themhave been in use for the treatment of various ailments. Plant synthesis hundreds of chemical compounds and have been tested for biological, antimicrobial, hypoglycemic, antiulcerogenic, antihelminthic, hepatoprotective, analgesic, antipyretic, antileishmania and insecticidal activities (Slutsker et al., 1998). Plants possessing these traits have been attributed to secondary metabolites synthesized by plants (Selvamohan et al., 2012).

Pseudarthria viscida (L.) Wight \& Arn. is a semi-erect sub-shrub, with slender, reddish brown branch lets, leaves are alternate, tri-foliate leaflets, distributed in the Indo-Malesian region and SriLanka. In India it is recorded in the states of Gujarat, Orissa, Karnataka, Tamil Nadu and Kerala. It is used in treatment of rheumatic arthritis, intestinal worm,

Corresponding Author:-Bharath Nair

Address:-Department of Forest Pathology, Kerala Forest Research Institute, Peechi-680653, Thrissur, Kerala. 
asthma, fever, dysentery, cardiac problems, tuberculosis, diabetes, piles, insect bites and to curebone fracture (Shanthakumar et al., 2009).

A number of endophytes have been found associated with various plant species which comprise bacterial and fungal colonies (Petrini and Fisher, 1990 and Arnold, 2000). Fungal endophytes form symbiotic associations and thrive in millions of unique ecological niches in many unusual environments almost ubiquitously throughout the plant kingdom and serves as an indirect defense against herbivores (Baccon and white 2000, Schulz et al., 2002; Strobel and Daisy 2003; Strobel et al., 2004; Bandara et al., 2006).

They have proven to be a promising source of new and biologically active natural products which are of interest for specific medicinal or agrochemical applications (Strobel, 2002). Several studies have demonstrated the ability of endophytic fungi to produce various compounds such as enzymes (Teske and Trentini, 1995; Bezerra et al., 2012b), antitumor substances (Chandra, 2012), antimicrobial substances (Souza et al., 2004; Siqueira et al., 2011) and plant growth hormones (Hwang et al., 2011). Industrial application resulted endophytes as an alternative tool for the mass production of the biologically active compounds (Zhao et al., 2010).

Although higher concentration of secondary metabolites might result in a more resistant plant, the production of secondary metabolites thought to be costly and reduces plant growth and reproduction. Hence plant have evolved induced defense, where concentration generally increase only in stress conditions (Simms et al., 1992). Hence the present study has been carried out to study antimicrobial ability of chloroform extract P. viscida and its associated major fungal endophyte and their phytochemical analysis using GCMS.

\section{Materials and Methods:-}

\section{Sample collection:-}

Healthy leaf sample of Pseudarthria viscida were randomly collected from in and around Kerala Forest Research Institute (KFRI) campus.

\section{Isolation of Endophytic Fungi:-}

The healthy leaf sample of P. viscida were washed 2-3 times under running tap water. Surface sterilization was performed by sequentially rinsing leaves with $70 \%$ ethanol for 2 minutes, then with $4 \%$ sodium hypochlorite for 60 seconds followed by ethanol for 30 seconds and finally rinse with sterile distilled water for 2-3 times.

The surface sterilized leaves were blotted and cut into small pieces $(2 \mathrm{~mm})$ and about 10 leaf segments were placed at equal distance on 5 plates of potato dextrose agar (PDA) and oat meal agar (OMA) supplemented with antibioticand incubated at $25 \pm 2^{\circ} \mathrm{C}$ for 5-7 days (extended to two weeks) under $12 \mathrm{hrs}$ alternating light and dark conditions to promote the growth of endophytes. Fungal colonies were isolated and identified on the basis of colony morphology, mycelium, fruiting-body, spore shape and size by referring standard manuals (Arx, 1981; Ellis and Ellis, 2001; Gilman, 1994; Ramarao and Manoharachary, 1990; Subramanian, 1983) and isolation frequency of various isolates were calculated using the formula:

Isolation frequency $(\mathrm{IF})=$ Number of single endophytic fungus isolated in each bits $\quad \times 100$

Total number of bits observed

\section{Preparation of Chloroform Extracts:- Plant Extract Preparation:-}

The selected plant (P. viscida) leaves were washed in running tap water, followed bysterile distilled water. They were shade dried at room temperature and ground into coarse powder. Powdered leaf samples were thoroughly mixed with chloroform and kept for three days provided with rotatory shaker and were filtered through Whatman No.1filter paper. The chloroform extracts of leaf samples were stored in darkness.

\section{Preparation of Fungal Extract:-}

The major endophytic fungus from the plant species was selected for extract preparation. Endophytic fungus was grown on PDA at $25 \pm 2^{\circ} \mathrm{C}$ for 7 days and ten mycelial discs $(7 \mathrm{~mm})$ were inoculated into 500 ml Erlenmeyer flasks 
containing $200 \mathrm{ml}$ of antibiotic amended potato dextrose broth (PDB) and incubated at $25 \pm 2^{\circ} \mathrm{C}$ for 15 days. The broth cultures were filtered through Whatman No.1filter paper and centrifuged to separate mycelial fragmentsand were denoted as mycelial mat extract (M.E.) and broth was denoted as culture filtrate (C.F.). Both the mycelial mat and culture filtrates were extracted with chloroform.

\section{Antimicrobial Assay:-}

Chloroform extracts of plant (P. viscida), mycelial mat and culture filtrate were tested for their antimicrobial activity against two bacteria (Escherichia coli and Staphylococcus aureus) and two fungi (Fusarium oxysporum and Cladosporium cladosporioides) at different concentrations $(25,50,75$ and 100 $\mu$ l) and incubated on Nutrient Agar (NA) medium at $37^{\circ} \mathrm{C}$ for bacteria and $25 \pm 2^{\circ} \mathrm{C}$ on PDA medium for fungi. The plates were observed after 24 hours of incubation for bacteria and after 7 days for fungi to determine minimum inhibitory concentration.

GC - MS Analysis:-

GC - MS analysis was carried out using QP2010S Shimadzu GC-MS instruments (30m x 0.25mm x 0.25 $\mathrm{mm}$, Rxi5Sil MS). $1 \mu \mathrm{l}$ of chloroform extract was injected into the GC-MS instrument. Initially the column temperature was maintained at $80^{\circ} \mathrm{C}$ for 2 minutes, followed by a temperature gradient from $80^{\circ} \mathrm{C}$ to $200^{\circ} \mathrm{C}$ and held constant for 2 minutes and finally raised temperature to $260^{\circ} \mathrm{C}$ and held constant for 2 minute. The instruments operated in a split mode and Libraries used for analysis were NIST 11\& WILEY 8.

\section{Results and Discussions:-}

Isolation and Identification of Endophytic fungi:-

Pseudarthria viscida leaves on PDA and OMA medium, resulted in the isolation of two endophytes namely Colletotrichum gloeosporioides (Pv-1) and C. lindimuthianum (Pv-2) (Table 1, Fig 1). Colletotrichum gloeosporioides was used to analyze its antimicrobial ability and for secondary metabolites. Various species of Colletotrichum have been isolated as endophytic fungi from various medicinal plants (Rakotonirianaet al., 2007, Gangadevi et al. 2008, Bhagyaet al., 2011).

Table 1:-Isolation frequency of Endophytic fungi from selected medicinal plants

\begin{tabular}{|l|l|l|l|l|}
\hline Sl.no. & Endophytic fungi & Morphological characteristics & \multicolumn{2}{l|}{$\begin{array}{l}\text { P viscida } \\
\text { Isolation frequency (IF) } \%\end{array}$} \\
\cline { 3 - 6 } & C. gloeosporioides & $\begin{array}{l}\text { Upper surface of colony white colony with orange } \\
\text { oozes at center, cottony in nature with striated } \\
\text { margin, hyaline. Reverse grayish black colony, } \\
\text { center hyaline and undulate margin, white or } \\
\text { hyaline. }\end{array}$ & 46 \\
\hline 2 & C. lindemuthianum & $\begin{array}{l}\text { Upper surface of colony greyish green colony } \\
\text { velvety in nature with undulate margin. Reverse } \\
\text { greyish black colony center hyaline with alternate } \\
\text { circles and undulate margin, white or hyaline. }\end{array}$ & 34 \\
\hline
\end{tabular}

Fig 1:-Endophytes isolated form Pseudarthria viscida. 


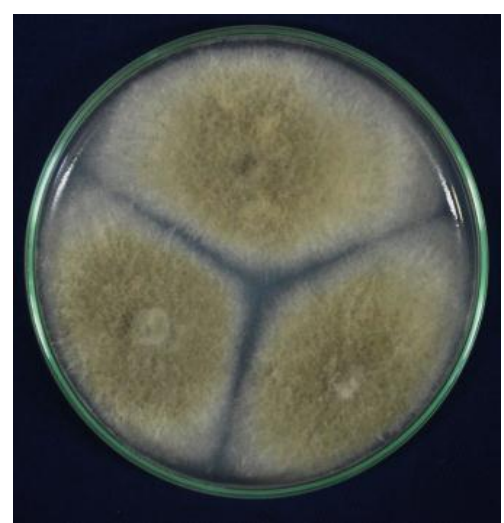

Pv-1- C. gloeosporioides

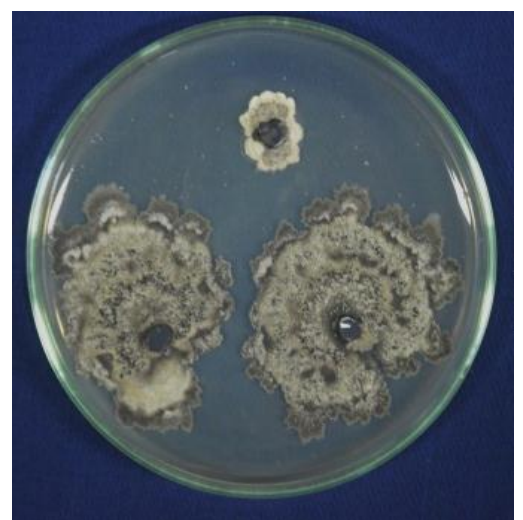

Pv-2- C. lindimuthianum

\section{Antimicrobial assay of chloroform extracts:-}

Chloroform extracts of the plant P. viscida, mycelial mat $(\mu \mathrm{g} / \mathrm{ml})$ and culture filtrate (v/v) of major endophyte Pv-1 (Fig 2, $3 \& 4$ ) were tested for their antimicrobial activity against two pathogenic bacterial species, Escherichia coli and Staphylococcus aureus and two fungal species, Fusarium oxysporum and Cladosporium cladosporioides. Different concentrations of extracts $(25,50,75$ and $100 \mu l)$ were studied. All the chloroform extracts were found to show good inhibitory activity against all the studied pathogens. Antibacterial activity of P. viscida showed an inhibition of 8-9 mm at all concentrations of extracts. On the other hand endophytic fungi Pv-1, both C.F. and M.E. showed inhibitory activity against E. coli at all concentrations and $25 \mu 1$ found to be minimum inhibitory concentration but against $\mathrm{S}$. aureus, $75 \mu \mathrm{l}$ of C.F. and $50 \mu \mathrm{l}$ of M. E. showed minimum inhibitory activity (Table 2 ).

Antifungal activity resulted in zone of inhibition against F. oxysporum by both, plant and fungal chloroform extracts. The Pseudarthria viscida plant extract showed an inhibition of $9-10 \mathrm{~mm}$ at all concentrations. In case of Pv1, both C.F. and M.E. all concentrations showed inhibitory activity against F. oxysporum. An inhibition of $8 \mathrm{~mm}$ in C.F. and $9 \mathrm{~mm}$ in M.E. at $25 \mu 1$ were found to be minimum inhibitory concentration. For C. cladosporioides, none of the concentrations of plantextractwere effective in the management of fungus. For endophyte Pv-1, C.F. and M. E. at concentration $100 \mu \mathrm{l}$ showed inhibition activity whereas rests of the concentrations were ineffective (Table 3). P. viscida methanol extract has been characterized by various workers for the identification of compounds and its antimicrobial activity (Baskar et al., 2012; Hemlal and Subban, 2012). Studies have shown potentiality of plant extracts against various microbial agents and standardization of solvent system for efficient activity.

Table 2:-Antibacterial activity of chloroform extracts of selected medicinal plants and fungal endophyte.

\begin{tabular}{|c|c|c|c|c|c|c|c|c|}
\hline \multirow{4}{*}{$\begin{array}{c}\text { Chloroform } \\
\text { extract }\end{array}$} & & & & \multicolumn{5}{|c|}{ Antibacterial activity } \\
\hline & \multicolumn{3}{|c|}{ S. aureus } & & & & & \\
\hline & \multicolumn{4}{|c|}{ Inhibition zone diameter(IZD) (mm) } & \multicolumn{4}{|c|}{ Inhibition zone diameter(IZD) (mm) } \\
\hline & $25 \mu \mathrm{l}$ & $50 \mu 1$ & $75 \mu 1$ & $100 \mu 1$ & $25 \mu 1$ & $50 \mu 1$ & $75 \mu 1$ & $100 \mu 1$ \\
\hline \multicolumn{9}{|c|}{ Plant extracts } \\
\hline P. viscida & 8 & 9 & 9 & 9 & 9 & 9 & 9 & 9 \\
\hline \multicolumn{9}{|c|}{ Fungal extracts } \\
\hline Pv-1 C.F. & - & - & 8 & 8 & 7 & 8 & 8 & 9 \\
\hline Pv-1 M.E. & - & 8 & 8 & 9 & 9 & 9 & 9 & 10 \\
\hline
\end{tabular}




\begin{tabular}{|c|c|c|c|c|c|c|c|c|}
\hline \multirow[t]{3}{*}{ extract } & \multicolumn{4}{|c|}{ Fusarium oxysporum } & \multicolumn{4}{|c|}{ Cladosporium cladosporioides } \\
\hline & \multicolumn{4}{|c|}{ Inhibition zone diameter (IZD) $(\mathrm{mm})$} & \multicolumn{4}{|c|}{ Inhibition zone diameter (IZD) (mm) } \\
\hline & $25 \mu 1$ & $50 \mu 1$ & $75 \mu 1$ & $100 \mu 1$ & $25 \mu 1$ & $50 \mu 1$ & $75 \mu 1$ & $100 \mu 1$ \\
\hline \multicolumn{9}{|c|}{ Plant extracts } \\
\hline P. viscida & 9 & 9 & 9 & 10 & - & - & - & - \\
\hline \multicolumn{9}{|c|}{ Fungal extracts } \\
\hline Pv-1 C.F. & 8 & 9 & 10 & 11 & - & - & - & 10 \\
\hline Pv-1 M.E. & 9 & 10 & 10 & 11 & _- & _- & _- & 10 \\
\hline
\end{tabular}

Table 3:-Antifungal activity of chloroform extracts of selected medicinal plants and fungal endophyte.

Fig 2:-Chloroform extracts of Pseudarthria viscidaleaves against microbes.

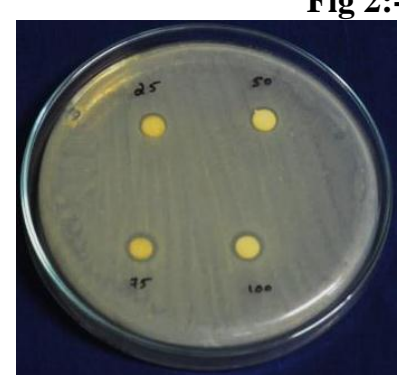

Staphylococcus aureus

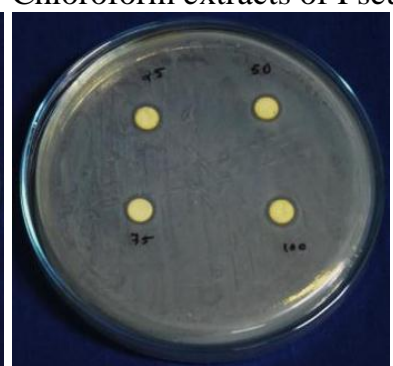

Escherichia coli

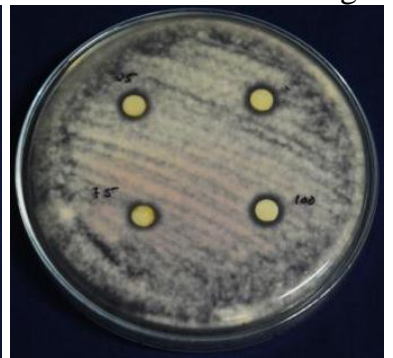

Fusariumoxysporum

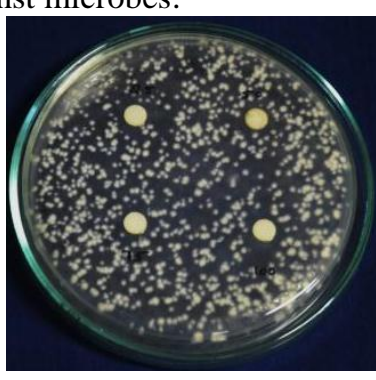

Cladosporium cladosporioides

Fig 3:-Chloroform extracts of Pseudarthria viscidaPv-1 C.F.against microbes

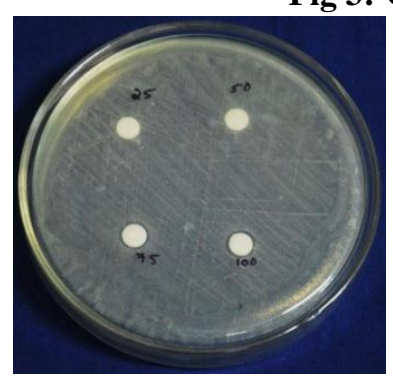

Staphylococcus aureus

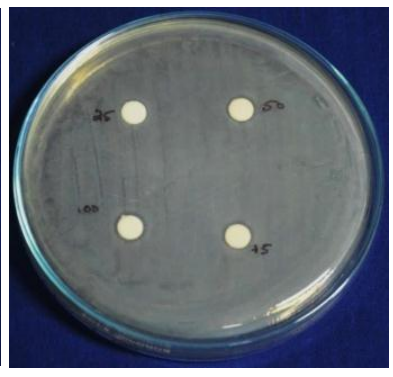

Escherichia coli

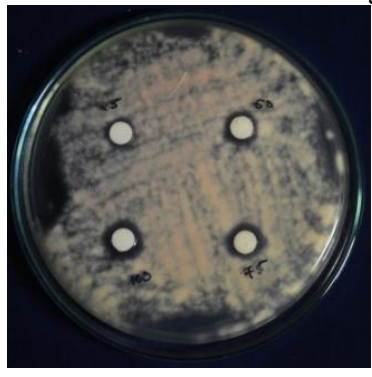

Fusariumoxysporum

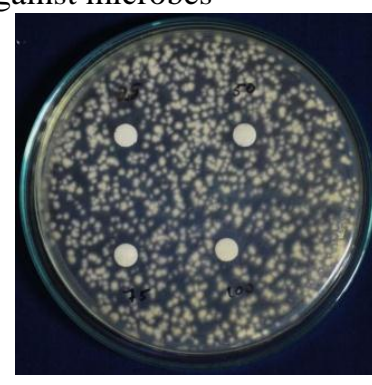

Cladosporium cladosporioides

Fig 4:-Chloroform extracts of Pseudarthria viscidaPv-1 M.E.against microbes.

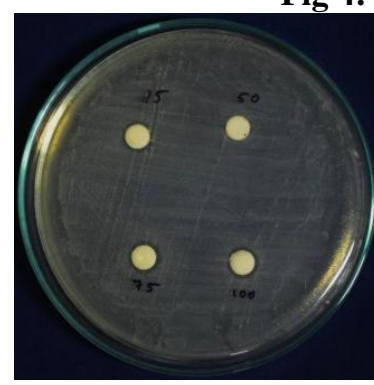

Staphylococcus aureus

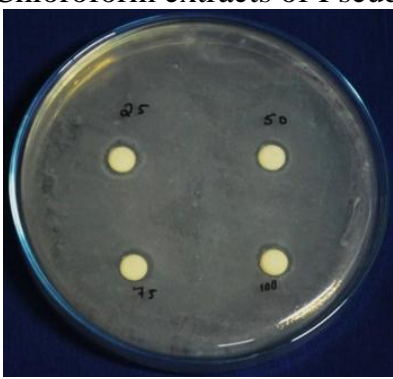

Escherichia coli

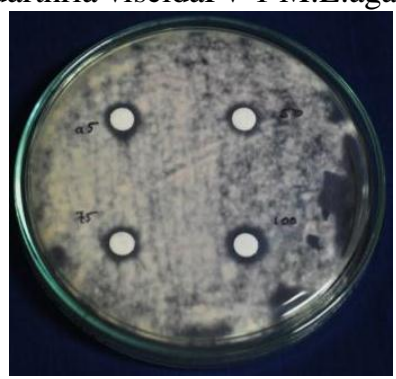

Fusarium oxysporum

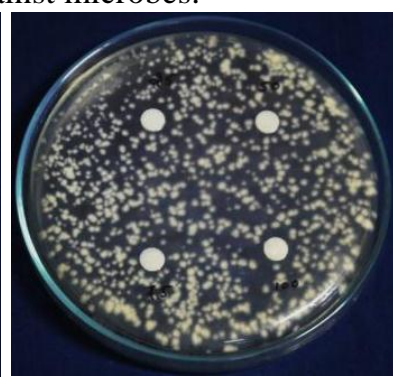

Cladosporium cladosporioides

Qualitative analysis of metabolites of plant and fungal extracts by GC-MS:- 
Phytochemical analysis of chloroform extracts of plant P. viscida (Table 4, Fig 5), culture filtrates and mycelial mat of endophyte Pv-1 (Table $5 \& 6$, Fig $6 \& 7$ ) resulted in the identification of different bioactive compounds. In the case of $\mathrm{P}$. viscidaand its endophyte Pv-1, 2,4-Ditert-butylphenol, E-14-Hexadecenal, E-15-Heptadecenal, 1Hexadecene, Cyclotetracosane, Octadecyl trifluoroacetate were found to be same. But the amounts of bioactive compounds (Area \%) present in the extracts varied. Methanol extracts of P. viscida plant have been studied by various authors and a number of different chemical compounds have been isolated (Baskar et al., 2012; Hemlal and Subban, 2012). The results suggested that most of the compounds present in the plant and associated endophyte possess potential therapeutic activities, the amount and purity of the compounds present need to be analysed further chemically for its effective isolation and application in various medicinal fields.

Table 4:-List of metabolites of P. viscida chloroform extract by GC-MS

\begin{tabular}{|l|l|l|l|l|l|l|l|}
\hline Peak\# & R. Time & Area & Area\% & Height & Height $\%$ & Name & Base $\mathrm{m} / \mathrm{z}$ \\
\hline 1 & 14.392 & 2844495 & 7.12 & 587929 & 5.31 & 1-TETRADECENE & 55.10 \\
\hline 2 & 16.760 & 479237 & 1.20 & 151406 & 1.37 & NONADECANE & 57.10 \\
\hline 3 & 17.352 & 7219352 & 18.06 & 1767712 & 15.97 & $\begin{array}{l}\text { 2,4-DITERT- } \\
\text { BUTYLPHENOL }\end{array}$ & 191.20 \\
\hline 4 & 19.296 & 4832781 & 12.09 & 1226694 & 11.08 & 1-HEXADECANE & 55.10 \\
\hline 5 & 19.465 & 450692 & 1.13 & 129797 & 1.17 & $\begin{array}{l}\text { UNDECANE,4,7- } \\
\text { DIMETHYL }\end{array}$ & 57.05 \\
\hline 6 & 23.758 & 5509259 & 13.78 & 1676797 & 15.15 & E-15-Heptadecenal & 55.10 \\
\hline 7 & 23.897 & 388754 & 0.97 & 122824 & 1.11 & PENTADECANE & 57.10 \\
\hline 8 & 24.644 & 2355748 & 5.89 & 848945 & 7.67 & Phytol, acetate & 68.10 \\
\hline 9 & 25.152 & 369695 & 0.92 & 136476 & 1.23 & $\begin{array}{l}3,7,11,15-\text { Tetramethyl-2- } \\
\text { hexadecen-1-ol }\end{array}$ & 57.10 \\
\hline 10 & 26.051 & 459876 & 1.15 & 159475 & 1.44 & $\begin{array}{l}7,9 \text {-Di-tert-butyl-1- } \\
\text { oxaspiro(4,5)deca-6,9-diene- } \\
\text { 2,8-dione }\end{array}$ & 57.10 \\
& & & & & & EICOSANE & 77.10 \\
\hline 11 & 26.120 & 499102 & 1.25 & 181798 & 1.64 & Tridecanol, 2-ethyl-2-methyl- & 57.10 \\
\hline 12 & 27.047 & 620886 & 1.55 & 192499 & 1.74 & E-14-Hexadecenal & 55.10 \\
\hline 13 & 28.085 & 5281916 & 13.21 & 1537257 & 13.89 & Cyclotetracosane & 57.10 \\
\hline 14 & 34.463 & 4150939 & 10.38 & 975023 & 8.81 & 1-TRICOSENE & 57.10 \\
\hline 15 & 39.526 & 2715658 & 6.79 & 821108 & 7.42 & Octadecyl trifluoroacetae & 57.10 \\
\hline 16 & 43.402 & 1794828 & 4.49 & 553605 & 5.00 & &
\end{tabular}

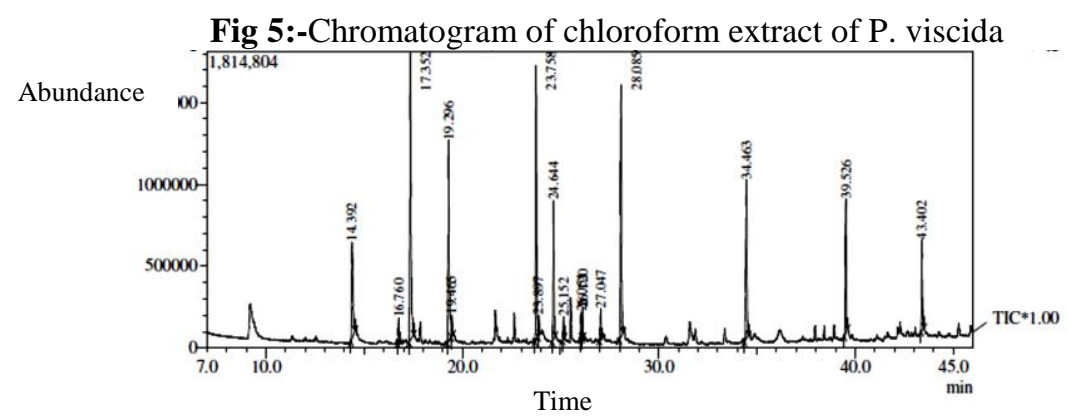

Table 5:-List of metabolites of chloroform extract of P. viscida C.F.of C. gloeosporioides Pv-1 by GC-MS.

\begin{tabular}{|l|l|l|l|l|l|l|l|}
\hline Peak\# & R. Time & Area & Area\% & Height & Height\% & Name & Base m/z \\
\hline 1 & 14.394 & 2128890 & 4.83 & 460741 & 4.50 & 1-PENTADECENE & 55.10 \\
\hline 2 & 17.358 & 9994117 & 22.65 & 2556925 & 24.98 & $\begin{array}{l}\text { 2,4-DITERT- } \\
\text { BUTYLPHENOL }\end{array}$ & 191.15 \\
\hline 3 & 19.294 & 3610069 & 8.18 & 1010046 & 9.87 & 1-HEXADECANE & 55.05 \\
\hline 4 & 19.468 & 528072 & 1.20 & 171602 & 1.68 & HEXADECANE & 57.10 \\
\hline 5 & 23.758 & 4091234 & 9.27 & 1305079 & 12.75 & E-14-Hexadecenal & 55.05 \\
\hline 6 & 23.901 & 545476 & 1.24 & 180860 & 1.77 & PENTADECENE & 57.10 \\
\hline
\end{tabular}




\begin{tabular}{|l|l|l|l|l|l|l|l|}
\hline 7 & 26.061 & 752121 & 1.70 & 239018 & 2.33 & $\begin{array}{l}\text { 7,9-Di-tert-butyl-1- } \\
\text { oxaspiro(4,5)deca-6,9-diene- } \\
\text { 2,8-dione }\end{array}$ & 57.10 \\
\hline 8 & 27.051 & 408314 & 0.93 & 138469 & 1.35 & $\begin{array}{l}\text { Tridecanol, 2-ethyl-2- } \\
\text { methhyl- }\end{array}$ & 57.10 \\
\hline 9 & 28.089 & 4175241 & 9.46 & 1080099 & 10.55 & E-15-Heptadecenal & 55.05 \\
\hline 10 & 28.251 & 383331 & 0.87 & 102195 & 1.00 & HEPTADECANE & 57.10 \\
\hline 11 & 34.463 & 3086662 & 7.00 & 742498 & 7.25 & Cyclotetracosane & 57.10 \\
\hline 12 & 36.285 & 6966190 & 15.79 & 437456 & 4.27 & Squalene & 69.10 \\
\hline 13 & 39.530 & 2144687 & 4.86 & 655848 & 6.41 & Heptadecyl trifluoroacetate & 57.10 \\
\hline 14 & 42.178 & 828912 & 1.88 & 234567 & 2.29 & $\begin{array}{l}\text { 1,2- } \\
\text { BENZENEDICARBOXYLIC } \\
\text { ACID }\end{array}$ & 149.05 \\
\hline 15 & 43.039 & 3343026 & 7.58 & 489615 & 4.78 & $\begin{array}{l}\text { 9(11)-Dehydroergosteryl } \\
\text { benzoate }\end{array}$ & 251.20 \\
\hline 16 & 43.409 & 1130770 & 2.56 & 432335 & 4.22 & Octadecyl trifluoroacetae & 57.10 \\
\hline
\end{tabular}

Fig 6:-Chromatogram of chloroform extract of P. viscida C.F.of C. gloeosporioides Pv-1

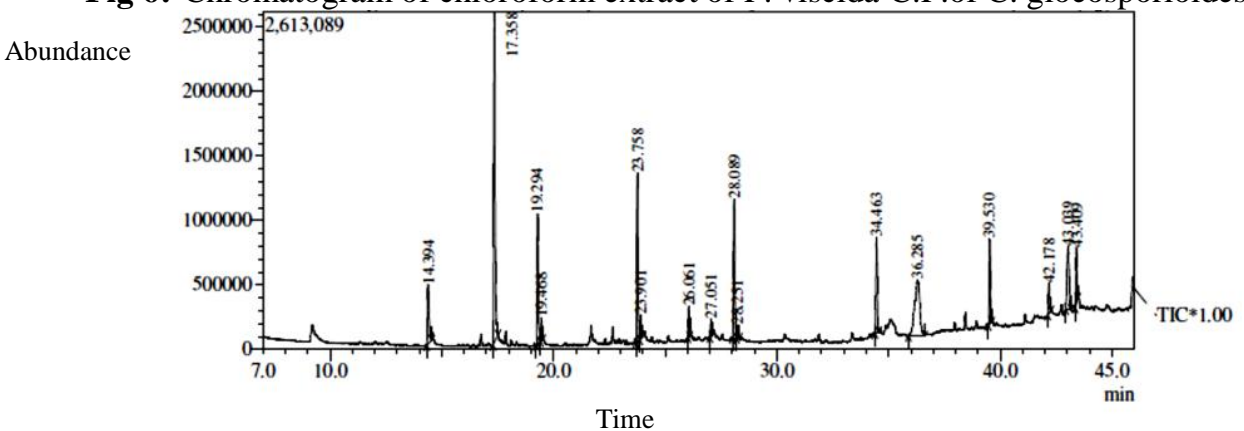

Table 6:-List of metabolites of chloroform extract of P. viscida M.E.of C. gloeosporioides Pv-1 by GC-MS

\begin{tabular}{|l|l|l|l|l|l|l|l|}
\hline Peak\# & $\begin{array}{l}\text { R. } \\
\text { Time }\end{array}$ & Area & Area\% & Height & Height\% & Name & $\begin{array}{l}\text { Base } \\
\mathrm{m} / \mathrm{z}\end{array}$ \\
\hline 1 & 9.219 & 5613391 & 5.83 & 549016 & 2.27 & $\begin{array}{l}\text { Cyclohexane,2-propyl-1,1,3- } \\
\text { trimethyl- }\end{array}$ & 128.10 \\
\hline 2 & 9.417 & 961531 & 1.00 & 188381 & 0.78 & Octane, 2,6-dimethyl- & 57.05 \\
\hline 3 & 14.396 & 6927889 & 7.20 & 1454947 & 6.01 & 1 -TETRADECENE & 55.05 \\
\hline 4 & 17.363 & 11289778 & 11.73 & 2903970 & 12.00 & $2,4-$-DITERT-BUTYLPHENOL & 191.15 \\
\hline 5 & 19.300 & 9644866 & 10.02 & 2824034 & 11.67 & 1-HEXADECANE & 55.10 \\
\hline 6 & 23.765 & 10420674 & 10.82 & 3461329 & 14.30 & E-14-Hexadecenal & 55.05 \\
\hline 7 & 23.905 & 1016460 & 1.06 & 321629 & 1.33 & PENTADECENE & 57.10 \\
\hline 8 & 24.122 & 1149117 & 1.19 & 189265 & 0.78 & $\begin{array}{l}\text { 1S,3R,4S,5R,6S-1-Hydroxy- } \\
2,2,3,4,5,6-\text {-hexamethyl-8-oxo-7,9- } \\
\text { dioxatricyclo[4.2.1.0(3,5)]nonane }\end{array}$ & 153.15 \\
\hline 9 & 26.067 & 1185726 & 1.23 & 232381 & 0.96 & $\begin{array}{l}7,9-\text {-Di-tert-butyl-1- } \\
\text { oxaspiro(4,5)deca-6,9-diene-2,8- } \\
\text { dione }\end{array}$ & 149.10 \\
\hline 10 & 28.100 & 13579814 & 14.11 & 3278862 & 13.55 & E-15-Heptadecenal & 55.05 \\
\hline 11 & 22.256 & 836380 & 0.87 & 229479 & 0.95 & EICOSANE & 57.10 \\
\hline 12 & 33.326 & 2983122 & 3.10 & 619781 & 2.56 & $\begin{array}{l}\text { ETHYL(9Z,12Z)-9,12- } \\
\text { OCTADECADIENOATE \# }\end{array}$ & 67.10 \\
\hline 13 & 33.564 & 4149536 & 4.31 & 869044 & 3.59 & (E)-9-Octadecenoic acid ethyl ester & 55.05 \\
\hline 14 & 34.505 & 10262087 & 10.66 & 2290738 & 9.47 & Cyclotetracosane & 57.10 \\
\hline 15 & 36.226 & 977802 & 1.02 & 101174 & 0.42 & 2,6-FARNESOL (CIS,TRANS) & 69.10 \\
\hline 16 & 38.475 & 943339 & 0.98 & 243435 & 1.01 & O O'-BIPHENOL,4,4',6,6'- & 57.10 \\
\hline
\end{tabular}




\begin{tabular}{|l|l|l|l|l|l|l|l|}
\hline & & & & & & TETRA-T-BUTYL- & \\
\hline 17 & 39.554 & 7291618 & 7.57 & 2174668 & 8.99 & 1-TRICOSENE & 57.10 \\
\hline 18 & 42.188 & 1018261 & 1.06 & 297827 & 1.23 & $\begin{array}{l}\text { 1,2-BENZENEDICARBOXYLIC } \\
\text { ACID }\end{array}$ & 149.05 \\
\hline 19 & 43.418 & 5098354 & 5.30 & 1765604 & 7.30 & Octadecyl trifluoroacetae & 57.10 \\
\hline 20 & 43.497 & 918262 & 0.95 & 205728 & 0.85 & OCTADECANE & 57.10 \\
\hline
\end{tabular}

Fig 7:-Chromatogram of chloroform extract of P. viscida M.E.of C. gloeosporioides Pv-1.

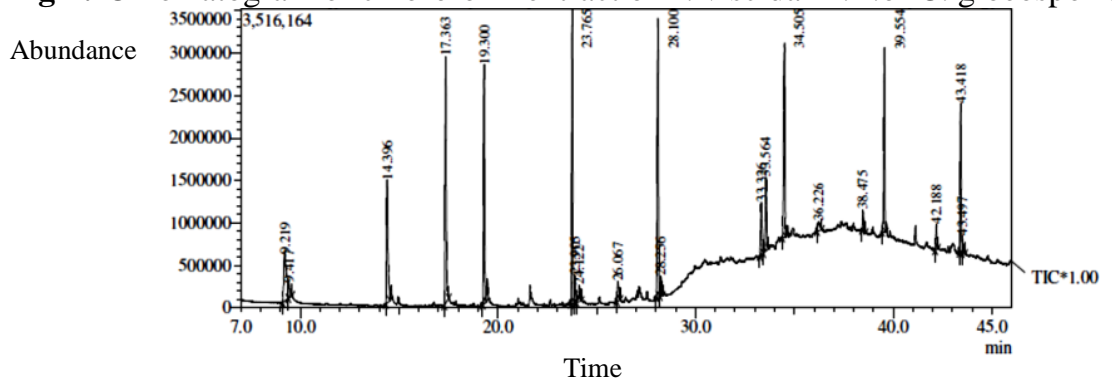

\section{Conclusions:-}

Medicinal plants and associated endophytes possess numerous bioactive compounds which forms an important source of new therapeutics. In the present study P. viscida were inoculated for the isolation of endophytes. Two endophytic fungi, Colletotrichum gloeosporioides and C.lindemuthianum were isolated and identified from P. viscida. Among these C. gloeosporioides from plant species was selected for further study. The chloroform extracts of plants and fungus, mycelia mat and culture filtrate were studied for antimicrobial activity and were found to be effective against selected microbes, E. coli, S. aureus, F. oxysporum and C. cladosporioides. Furthermore, active crude extract were subjected for the isolation and identification of biologically active secondary metabolite via GCMS which may provide better source for developing new therapeutic agents. The obtained metabolites need evaluation and further attempts may be required in order to isolate and identify the secondary metabolites responsible for antimicrobial activity reported here.

\section{Acknowledgements:-}

The authors are grateful to the Director, Kerala Forest Research Institute for encouragement and also all the Forest pathology department lab members, KFRI.

\section{Reference:-}

1. Arnold, A.E., Maynard. Z., Gilbert, G.S., Coley, P.D. and Kursar, T.A. (2000). Are tropical fungal endophytes hyperdiverse? Ecology Letters, 3, 267-274.

2. Arx, V. J. A. (1981). The genera of fungi sporulating in pure culture, J. Cramer. In der A.R. Gantner Verlag Kommanditgesellschaft. FL - 9490, Vaduz. 424.

3. Baccon, C.W. and White, J.F. (2000). Microbial endophytes. Marcel Dekker, New York, pp. 341-388.

4. Bandara, W. M. M. S., Seneviratne, G., Kulasooriya, S.A. (2006). Interactions among endophytic bacteria and fungi: effectsand potentials. J Biosci 31(5):645-650.

5. Baskar, N., Jaiganesh,K.P., Nepolean, R. and Selvakumar, N. (2012). Evaluation of antimicrobial activity of methanolic extract of the Pseudarthria viscida linn. International Journal of Pharmaceutical and Chemical sciences, Vol. 1 (4).

6. Bezerra, J.D.P., Nascimento, C.C.F., Barbosa, R., Silva, D., Svedese,V., Silva-Nogueria, E.,Gomes, B., Paiva, L. and Souza-Motta, C. (2015). Endophytic fungi from medicinal plant Bauhinia forficate: Diversity and biotechnological potential. Brazilian Journal of microbiology 46,1, 49-57.

7. Bhagya, N., Sheik, S., Sharma, S.M. and Chandrashekar, K.R. (2011). Isolation of endophytic Colletotrichum gloeosporioides Penz. From Salacia chinensis and its antifungal sensitivity. Journel of Phytology, 3(6):20-22.

8. Chandra, S. (2012). Endophytic fungi: novel sources of anticancer lead molecules. Appl Microbiol Biot 95:4759. 
9. Ellis, M. B. and Ellis, J. P. 2001. Microfungi on land plants an identification handbook. Croom helm Australia Pvt. Ltd., Sydney, Australia. 818.

10. Gangadevi, V. and Muthumary, J. (2008). Isolation of Colletotrichum gloeosporioides, a novel endophytic taxol- producing fungus from the leaves of a medicinal plant, Jusriciagendarussa. Mycologiabalcanica 5: 1-4.

11. Gilman, J. C. (1994). A manual of soil fungi. The Iowa state college Press-Ames, Iowa, USA.450.

12. Hemlal, H. and Ravi, R. (2012). GC-MS, HPTLC and Antimicrobial analysis of Root extracts of Pseudarthria viscida Wight and Arn and Desmodium gangeticum (Linn) DC.International Research Journal of Biological Sciences Vol. 1(5), 57-65.

13. Hwang, J. S., You, Y. H., Bae, J. J., Khan, S. A., Kim, J. G. and Choo, Y. S. (2011) Effects of endophytic fungal secondary metabolites on the growth and physiological response of Carex kobomugi Ohwi J Coastal Res 27:544-548.

14. Petrini, O. and Fisher, P.J. (1990). Occurrence of fungal endophytes in twigs of Salix fragilis and Quercus robur.Mycological Research 94: 1077-1080.

15. Rakotoniriana, E.F., Munaut, F.,Decock, C., Randriamampionona, D., Andriambololoniaina, M., Rakotomalala, T., Rakotonirina, E.J., Rabemanantsoa, C., Cheuk, K., Ratsimamanga, S.U., Mahillon., El-Jaziri, M., QuetinLeclercq, J. and Corbisier, A.M. (2007) Endophytic fungi from leaves of Centella asiatica: occurrence and potential interactions within leaves. Springer Science+Business Media B.V.

16. Ramarao, P. and Manoharachary, C. (1990). Soil fungi from Andhra Pradesh. Department of Botany, Osmania University. 164.

17. Schulz, B., Boyle, C., Draeger, S., Rommert, A.K. and Krohn, K.(2002). Endophytic fungi: a source of novel biologically active secondary metabolites. Mycol Res, 106:996-1004.

18. Selvamohan, T., Ramadas, V. and Kishore, S. (2012). Advance in applied science research, 3(5): 3374-3381.

19. Shanthakumar, S., Saravanan, C., Anandan, R., Narayanswamy, V. B. and Varunraj, S. (2009). Anti-Pyretic and Anti-Nociceptive activity of Alcoholic extract of Pseudarthriaviscida. The pharmacist 4 (2): 27-30.

20. Simms, E. L. (1992). Costs of plant resistance to herbivoryin R. S. Fritz, and E. L. Simms (eds.). Ecology and Evolution of Plant Resistance. University of Chicago Press, Chicago. pp. 392-495.

21. Siqueira, V. M., Conti, R., Araujo, J. M. and Souza-Motta, C. M. (2011). Endophytic fungi from the medicinal plant Lippiasidoides Cham. and their antimicrobial activity. Symbiosis 53: 89-95.

22. Slutsker, L., Alterkurse, S.F. and Swerdloe, D.L. (1998). Food borne diseases: emerging pathogen and trends. Infect. Dis. clin. North. Am. 12: 199-216.

23. Souza, A.Q.L., Souza, A.D.L., Astolfi-Filho, S., Pinheiro, M.L.B., Sarquis, M.I.M., Pereira, J.O. (2004). Antimicrobial activity of endophytic fungi isolated from amazonian toxic plants: Palicourea longiflora (aubl.) rich and Strychnos cogens bentham. Acta Amaz 34:185-195.

24. Strobel, G. A. (2002).Microbial gifts from the rain forest. Canadian Journal of Phytopathology, 24: 14-20.

25. Strobel, G. and Daisy, B. (2003). Bioprospecting for microbial endophytes and the natural products. Microbiology and molecular biology reviews 67 (4), 491-502.

26. Strobel, G., Daisy, B., Castillo, U. and Harper J. (2004). Natural Products from Endophytic Microorganisms. J Nat Prod, 67(2): 257-68.

27. Subramanian, C. V. 1983. Hypomycetes. Taxonomy and Biology. Academic Press, London, Vol. I and II. 930.

28. Teske, M., Trentini, A.M.M. (1995). Compêndio de Fitoterapia. Herbarium Lab. Botânico, Curitiba.

29. Zhao, J., Li, C., Wang,W., Zhao, C. and Luo, M. (2013). Hypocrea lixii, novel endophytic fungi producing anticancer agent cajanol,isolated from pigeon pea (Cajanuscajan [L] mill sp.). J Appl Microbiol, 115:102-103. 